\title{
Valorization Methodology for Agriculture Sector Climate Change Mitigation Measures
}

\author{
Agita GANCONE ${ }^{1}$, Jelena PUBULE ${ }^{2 *}$, Dagnija BLUMBERGA ${ }^{3}$ \\ ${ }^{1-3}$ Institute of Energy Systems and Environment, Riga Technical University, Riga, Latvia
}

\begin{abstract}
Agriculture sector holds an essential role in Latvia's economy and play significant role in keeping rural areas as a habitable environment (approximately $32 \%$ of the population lives in rural areas). The agricultural sector is responsible for $28.5 \%$ (2018) of total nonEuropean Union Emissions Trading System (non - EU ETS) greenhouse gas (GHG) emissions in Latvia. The largest part of emissions is related to agricultural soils $(59.3 \%)$ and enteric fermentation $32.6 \%$ (mainly dairy and beef cattle). The GHG emissions trend of recent years shows a gradual and steady increase in GHG emissions for example between 2005 and 2018 $+12.5 \%$ and during the period 2013-2018 emissions increased by $2.12 \%$. According to Latvia's National Energy and Climate Plan 2021-2030 (NECP), total GHG emissions in the agricultural sector are expected to increase in the period from 2020 to 2030 , mainly in the enteric fermentation and agricultural soil categories. To achieve determined targets for Latvia's non-EU ETS sector in 2030 and be on track to reach climate neutrality in 2050 , the agricultural sector has to contribute to GHG emission mitigation. For the agricultural sector, improved food security and climate smart activities will be necessary to achieve GHG emission reduction. Existing policies and measures (WEM) as well as those which are included in the NECP as additional measures (WAM) were used to assess more suitable measures to move on climate smart agriculture (CSA), that could help to decrease GHG emissions at the farm and state level as well as is expected to contribute towards achieving the commitments in the plan. To achieve the aim of the study, a combination of the Delphi method together with multi-criteria analysis (MCA) is utilized to find a set of top GHG mitigation measures in the future. Results show that, in the future, the measure support the development of innovative technologies and solutions to promote resource efficiency in agriculture is essential to move on climate smart agriculture.
\end{abstract}

Keywords - Climate smart agriculture; sustainable agriculture; Delphi method; GHG emissions; innovative technology; measures, mitigation

\section{INTRODUCTION}

Latvia reduced GHG emissions from agriculture between 1990 and 2018 by $53 \%$, however in the latest years and future projections, a rising trend has developed [1]-[5]. In the agriculture sector, the increase in emissions is projected to be lower with implementation of additional policies and measures (WAM) scenario, e.g. support to precision farming practices, the reduction of nitrogen fertilizer use and biogas production than in the scenario with existing measures (WEM) 8.2\% [5]. According to the European Green Deal, it is planned to improve people's well-being and making Europe climate-neutral including a decrease of emissions while creating jobs [7]. To move on these ambitions, the European Commission proposes to revise relevant climate policies, for example, targets to reduce emissions in sectors outside

* Corresponding author.

E-mail address: jelena.pubule@rtu.lv 
the EU ETS. To reach these ambitions, action will be required by all sectors of the economy, including agriculture nevertheless it is not so easy. One of the main challenges facing the agricultural sector is to provide food for increasing population at the same time reducing its influence on the climate and the environment [8]-[10]. According to the Intergovernmental panel on climate change (IPCC) Synthesis report (2015), the most profitable mitigation possibility is cropland and grazing land management as well as organic soils renewal in agriculture. Efficient mitigation and adaptation are related to implementation of policies and measures at several levels, including avoidance of use of less labour-intensive technologies in the agricultural sector [11], [12].

The Farm to Fork Strategy determines matters of sustainability of food as well the support granted to farmers. This Strategy includes the following main targets: agriculture of EU be organic $25 \%$ by 2030 , decrease the utilization of pesticides by $50 \%$ until 2030, reduce use of fertilizers by $20 \%$ by 2030 , decrease loss of nutrients in soil at least $50 \%$, decrease antimicrobials use in agriculture and in aquaculture by 2030 by $50 \%$, create food labelling sustainable, reduce wastes of food by $50 \%$ by 2030 . All these mentioned initiatives include moving on climate smart agriculture (CSA) and contribute to the achievement of the sustainable development goals [13].

In literature there are more definitions related to CSA. In 2009, for the first time the CSA idea was initiated [14]. The term was reflected at the Hague Conference on Agriculture, Food Security and Climate Change by the Food and Agriculture Organization of the United Nations (FAO) in 2010 [15]. According to the FAO often used definition of CSA agriculture is that increases productivity in a sustainable way, increases resistant, decreases GHG, and increases the achievement of national food security and goals of development [16]. Lipper et al. also noted that definition and essential aim of CSA is the development and security of food [17] and productivity, adaptation, mitigation are pointed out as three interconnected activities to reach this aim. As well Lipper et al. [17] say that CSA could be explained as an approach for reorienting and transforming agricultural development taking into account climate change. However, A. Amin et al. stated that CSA can be determined as agricultural productivity growing in a sustainable way, building and adapting resilience to climate change, GHG emission reduction [18] as well as that it is a possibility to increase the policy, technical, and investment on the environment to get continual agricultural growth for food protection due to change of climate. As it is written by L. Lipper and D. Zilberman [14], CSA aims to provide comprehensive appropriate principles of agricultural management for food security due to climate change that would ensure a foundation upon which to build policy support as well as recommendations of organizations. FAO emphasizes three objectives of CSA (see Fig. 1.) [19], which can contribute to achieve the Sustainable Development goals.

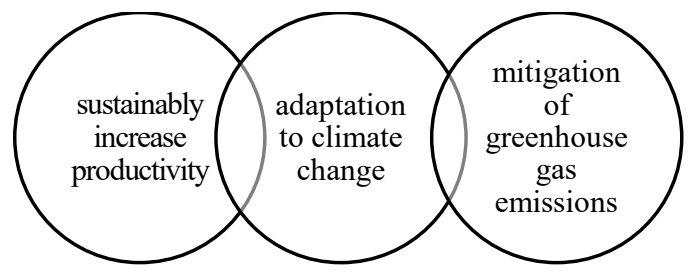

Fig.1. Objectives of climate smart agriculture.

It is recognized that to reach the objectives set in Fig. 1, agricultural production and food systems will need to use natural resources and other inputs in a more efficient way and become more resilient to change [20]. 
CSA is also mentioned in literature as an integrated approach to better adapt crops and livestock to climate change as well as agricultural methods, and thus reduce GHG emissions, considering also technological and environmental availability factors [21] at the same time taking into consideration the growing population for which there needs to be a guarantee in food security [22]. Thus, the emphasis is not simply on sustainable agriculture, but also on increasing agricultural productivity. The CSA is consistent with the vision of FAO and also supports the aim to turn agriculture into a more sustainable and efficient sector [15].

Smart agriculture is directed towards guiding the land supply and depending on its status, focusing on suitable growing parameters, such as material content, fertilizer, moisture - to ensure production of the appropriate crop that is in demand. The ways precision farming is implemented depends on the software used by sustainable entrepreneurs [23]. In the management of agriculture, reasonable intensification is necessary [24] and CSA is the solution [25]. Challenges related to climate change in the agricultural sector ask for acceptance of innovative methods in order to increase resilience, decrease influence, while supporting the productivity of the farm [26]. This set of activities has been also widely indicated by the FAO (2010).

Many policy instruments might be implemented for CSA practices adoption in agriculture sector, for example, regulatory and economic instruments (taxes, compensations) as well as on information-based instruments (e.g. Certification and labelling) [27]. The EU encourages Member States to include CSA principles in their Strategic Plans of Common Agriculture Policies through economic instruments.

Two methods (approaches) were used to enhance the methodology for agriculture sector to valorize climate change mitigation measures:

1. Delphi method;

2. Multi-criteria analysis.

Using the Delphi approach or technique in analysis of information it can be also deemed as Evaluate-Talk-Evaluate [28]. In literature the first use of the Delphi method is mentioned to have been used for technology projections and science and it was applied in economic trends, education and health [29].

\section{Methodology}

The objective of this study is the evaluation of a methodological approach for the mitigation GHG emissions from the agricultural sector in a way which is climate smart. To meet the aim of the study, the methodological concept used is the combination of the Delphi method together with multi-criteria analysis. The ETE approach is used to get expert opinions regarding existing and planned policies and measures for GHG emission reductions in the agricultural sector. The aim of the method is to collect the opinions and judgments of experts about issues in terms of possibilities in the future, likelihood and usefulness of implementation [30]. The approach of the method - the opinions of the experts are summarized in a process of communication by a planned group [28]. The method of Delphi is formulated on the idea that future predictions from a planned group of individuals are more precise if compared to unplanned groups [29]. The main characteristics of the Delphi method are: experts can remain anonymous, management of the survey is in several rounds, and feedback can be sought from the experts [30]. Experts were selected according to their competence. Nineteen GHG reduction measures with existing policies and measures and with additional policies and measures were included in the survey. These measures are taken from Latvia's latest submitted fourth biennial report (Latvia's BR4) to the United Nations Convention on Climate Change (UNFCCC) and from Latvia's National Energy and Climate 
Plan 2021-2030 [31], [32]. Each of the experts was asked to assess these nineteen mitigation measures from an economic, engineering-technical, environmental/climate and social aspect.

The initial inputs of the experts are in the form of answers to the questionnaire and their comments on these answers. The questionnaire was sent to 25 experts with knowledge on the issue. Experts were asked to prepare their own opinion/prediction. All participants remained anonymous. 18 experts answered questionnaires in two rounds. Experts provided answers and additional descriptions and judgments.

Between these two rounds of the survey, a multi criteria analysis was performed, which allows for the prioritization and assessment of different measures from the economic, technical, environment/climate and social perspective. It is stated by Pubule et al., that multi criteria analysis generally includes a weighted set of criteria [33]. To assess and find the most optimal scenario, TOPSIS (the Technique for Order of Preference by Similarity to Ideal Solution) was used, which was made by Hwang and Yoon [34]. The goal of this approach is to help in making a decision by grouping alternatives according to how they fit in with the best solution [35].

Additionally, experts were asked to consider first round replies taking into account the answers of other experts to get an overview/opinion regarding future projections for the most appropriate measures for GHG reduction and for a move to smart agriculture, where the efficient use of resources is one of the main goals.

The basic concept scheme used for the evaluation is shown in Fig. 2.

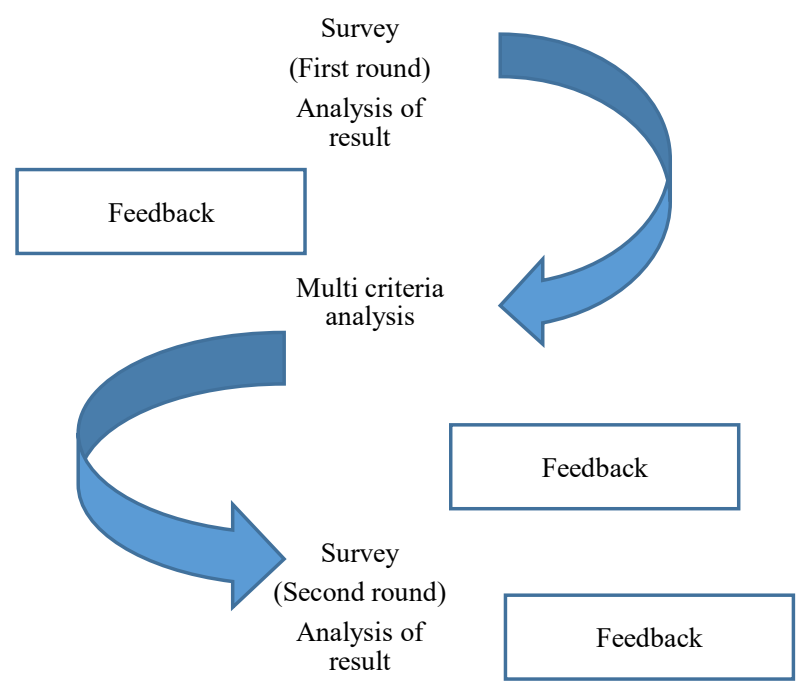

Fig. 2. Scheme of the used Delphi technique and TOPSIS for analysis.

A set of WEM and WAM policies and measures implemented, adopted and planned in Latvia's BR4 and NECP 2021-2030 focuses on developing programs and implementing measures on farms in different clusters to reduce GHG emissions from the agricultural sector. The following key policies and measures were reported in Latvia's BR4: increased land area of organic farming, legumes growing, support for advancing precision farming technologies and livestock feeding practices, promoting the reduced use of nitrogen fertilizers, including biogas production, maintenance of amelioration systems [36]. 
As the trend of GHG emissions from the agricultural sector shows an increase of emissions, the NECP includes the following to solve this problem: measures to promote the precise and efficient use of fertilizers, direct injection of slurry in soil; measures to improve soil fertility maintenance of drainage systems, nitrogen sequestering crops as a part of crop rotation, under sowing grass, green fallow; measures that improve animal nutrition - improvement of feed quality, feed ration planning; measures to improve manure management systems - promotion of biogas production, organic dairy farming [37]. Unfortunately, a budget is not provided for all planned measures, therefore the implementation of these measures may be jeopardized. Research of Latvia's University of Life Sciences and Technologies related to GHG reduction measures are used for determination of appropriate additional measures and policies for Latvia's agriculture in the NECP [38]. Popluga D., Naglis-Liepa K. indicate that beneficial management practices are one of the globally most recognized methods to evaluate GHG emission potential and applied this approach to determine the following measures as the most appropriate - introduction of leguminous plants on arable land, nitrogen balance, lengthened grazing season, strategies of feeding, production of biogas [36], [39]-[41]. To evaluate the more eligible GHG emission decreasing measures for Latvia, a marginal abatement cost curve (MACC) was used [42].

Below are short descriptions of some of the GHG reduction measures and policies for WEM and WAM scenarios for the agricultural sector according to Latvia's BR4 and NECP [4], [3]:

- Use of precision agriculture technologies in farms for crop growth to reduce use of nitrogen - related with the use of nitrogen fertilizer reduction and thus reduction of nitrogen leaching and run-off. This measure reduces nitrous oxide emissions from agricultural soils;

- Promotion of precision cattle feeding approach, including feeding plan development and support the use of good quality feed for increasing digestibility - the aim of this implemented measure is to contribute to the use of good quality food for livestock thus decreasing methane emissions and increasing digestibility;

- Introduction of leguminous plants on arable land - related to the use of pulses as fodder and manure in the rotation of crops and thereby contributing to the use of nitrogen fertilizer reduction. This measure could reduce emissions of nitrous oxide from the use of inorganic $\mathrm{N}$ fertilizers and organic $\mathrm{N}$ fertilizers. Financial support is provided for the implementation of this measure according to national legislation;

- Management of nitrate vulnerable territories - related to the restriction of nitrogen usage and thus nitrogen leaching reduction as well as protection of water pollution from nitrates;

- Water and soil protection requirements from pollution-related nitrates - measure to restrict nitrogen usage and reduce nitrogen leaching. This measure reduces indirect $\mathrm{N}_{2} \mathrm{O}$ emissions from managed agricultural soils;

- Crop fertilization plans in vulnerable zones - measure for farmers in highly vulnerable areas who have an area of 20 and more hectares and grows potatoes, vegetables and are required to document the field history for at least three years, if fertilizers are used.

- Requirements for manure storage and spreading - related to requirements of manure storage outside the animal shed and is for farms in vulnerable territories;

- Maintenance and modernization of amelioration systems on agricultural land measure reduces indirect $\mathrm{N}_{2} \mathrm{O}$ emissions from $\mathrm{N}$ leaching and run-off from agricultural land and is used for implementation in croplands on mineral soils, where, due to unfriendly circumstances, are not easy to get high yields, especially in the spring time, which are induced by drainage systems wearing. Financial support for renovation of a 
drainage system is made according to established national legislation. Modernization of amelioration systems on agricultural land is planned to increase arable land area with improved and maintained amelioration systems, thereby reducing nitrogen leaching and run-off from agriculture land;

- Promotion of biogas production - measure for usage of bioresources (mainly or only manure) to produce biogas which is used to generate electrical and/or thermal energy. By implementing this measure, the manure is efficiently used, the odor is reduced and a high-quality fertilizer called digestate is obtained;

- Organic farming land area increase - related to methods of farming with inorganic nitrogen fertilizers use reduction and leaching, increased biodiversity and environmentally favorable impact on nature;

- Extensified crop rotation - related with use of green manure in rotation of crops and promoting organic dairy farming. The main aim of the measure is to promote transition of small and medium-sized conventional dairy farms to the organic farming system, thus facilitating low emission dairy farming;

- Support for fertilization planning - the main aim of the measure is to expand arable land and increase the number of medium-sized crop and livestock farms where fertilization planning and practical implementation that is based on knowledge about agrochemical properties of soil has not been done previously;

- Promote inclusion of leguminous plants in crop rotation for nitrogen fixation - the main aim of the measure is to expand arable land and increase number of farms where leguminous plants are included in crop rotation thus contributing to atmospheric nitrogen fixation and reduction of application of inorganic nitrogen fertilizers;

- Promote and support for precision application of inorganic nitrogen fertilizers related to expanding arable land and increasing number of farms where precision technologies for application of inorganic nitrogen fertilizers are used in the planning of fertilizer schemes and spreading;

- Promote and support for direct incorporation of organic fertilizers into the soil (using specific technology) - related to expanding arable land where organic fertilizers are directly incorporated into the soil thus promoting more efficient use of organic fertilizers;

- Promote feed ration planning - related to increased number of cows the feed rations of which are balanced for reduced crude protein level without loss in milk production;

- Promote improvement of feed quality - related to increasing the number of cows who are fed with feed (in this measure special attention is paid to hay, hay silage, grass silage) with high digestible energy (i.e. digestible energy is more than $68 \%$ );

- Promote biogas and biomethane production and biomethane use - related to ensure the installation of biogas production and biogas purification (biomethane production) facilities on farms that have not yet had biogas production and purification facilities;

- Support the development of innovative technologies and solutions to promote resource efficiency, $\mathrm{GHG}$ reduction/ $\mathrm{CO}_{2}$ sequestration in agriculture - measure whereby support will be provided for the development of the new technologies and innovative solutions for GHG emission reduction and increase of $\mathrm{CO}_{2}$ removal. Unfortunately, the financial source is not indicated. 


\section{Results}

This paper introduced a way of measuring policies and measures in the agricultural sector for evaluation GHG reduction based on the Delphi method and multi criteria analysis where the criteria taking into account include: economic, engineering-technical, environmental/climate and social. Criteria weights were determined by experts.

\section{TABLE 1. WeIGHTED NORMALISED MATRIX}

\begin{tabular}{|c|c|c|c|c|}
\hline Measures & Economical & Technical & Climate & Social \\
\hline $\begin{array}{l}\text { Promote and support for precise application of inorganic } \\
\text { nitrogen fertilisers }\end{array}$ & 0.075 & 0.070 & 0.073 & 0.022 \\
\hline Support for fertilisation planning & 0.088 & 0.074 & 0,074 & 0.023 \\
\hline Requirements for manure storage and spreading & 0.063 & 0.065 & 0,075 & 0.022 \\
\hline $\begin{array}{l}\text { Promote and support for direct incorporation of organic } \\
\text { fertilisers into the soil }\end{array}$ & 0.060 & 0.064 & 0.070 & 0.023 \\
\hline $\begin{array}{l}\text { Use of precision agriculture technologies in farms for crop } \\
\text { growing to reduce use of nitrogen }\end{array}$ & 0.074 & 0.068 & 0.072 & 0.022 \\
\hline $\begin{array}{l}\text { Promote inclusion of leguminous plants in crop rotation for } \\
\text { nitrogen fixation }\end{array}$ & 0.073 & 0.072 & 0.071 & 0.024 \\
\hline $\begin{array}{l}\text { Support and promote intercropping system in cereal } \\
\text { growing }\end{array}$ & 0.065 & 0.063 & 0.060 & 0.021 \\
\hline $\begin{array}{l}\text { Support and promote green fallow introduction before } \\
\text { winter crop sowing }\end{array}$ & 0.064 & 0.067 & 0.057 & 0.022 \\
\hline Promote organic dairy farming (low emission dairy farming) & 0.061 & 0.071 & 0.068 & 0.027 \\
\hline $\begin{array}{l}\text { Promote precision cattle feeding approach, including } \\
\text { feeding plan development and support good quality use of } \\
\text { feed to increase digestibility }\end{array}$ & 0.087 & 0.079 & 0.072 & 0.023 \\
\hline Promote improvement of feed quality for cattle farms & 0.078 & 0.074 & 0.070 & 0.024 \\
\hline Promote biogas production & 0.060 & 0.064 & 0.072 & 0.024 \\
\hline $\begin{array}{l}\text { Promote biogas and biomethane production and biomethane } \\
\text { use }\end{array}$ & 0.060 & 0,062 & 0,073 & 0,025 \\
\hline $\begin{array}{l}\text { Maintain and modernise amelioration systems on } \\
\text { agricultural land }\end{array}$ & 0.070 & 0.066 & 0.061 & 0.023 \\
\hline $\begin{array}{l}\text { Promote the conservation of perennial grassland on } \\
\text { livestock farms }\end{array}$ & 0.057 & 0.072 & 0.068 & 0.023 \\
\hline Management of nitrate vulnerable territories & 0.063 & 0.067 & 0.057 & 0.019 \\
\hline $\begin{array}{l}\text { Water and soil protection requirements from pollution- } \\
\text { related nitrates }\end{array}$ & 0.059 & 0.062 & 0.064 & 0.022 \\
\hline $\begin{array}{l}\text { Create a map of the distribution of peat soils on agricultural } \\
\text { land }\end{array}$ & 0.066 & 0.067 & 0.070 & 0.022 \\
\hline $\begin{array}{l}\text { Support the development of innovative technologies and } \\
\text { solutions to promote resource efficiency, } \mathrm{GHG} \\
\text { reduction/ } \mathrm{CO}_{2} \text { sequestration in agriculture }\end{array}$ & 0.072 & 0.074 & 0.074 & 0.025 \\
\hline
\end{tabular}


Based on the results of the first round of the survey, TOPSIS was used. A normalized and weighted matrix for decision making of the evaluation of measures to reduce GHG emissions in the agricultural sector are shown in Table 1 and Fig. 3.

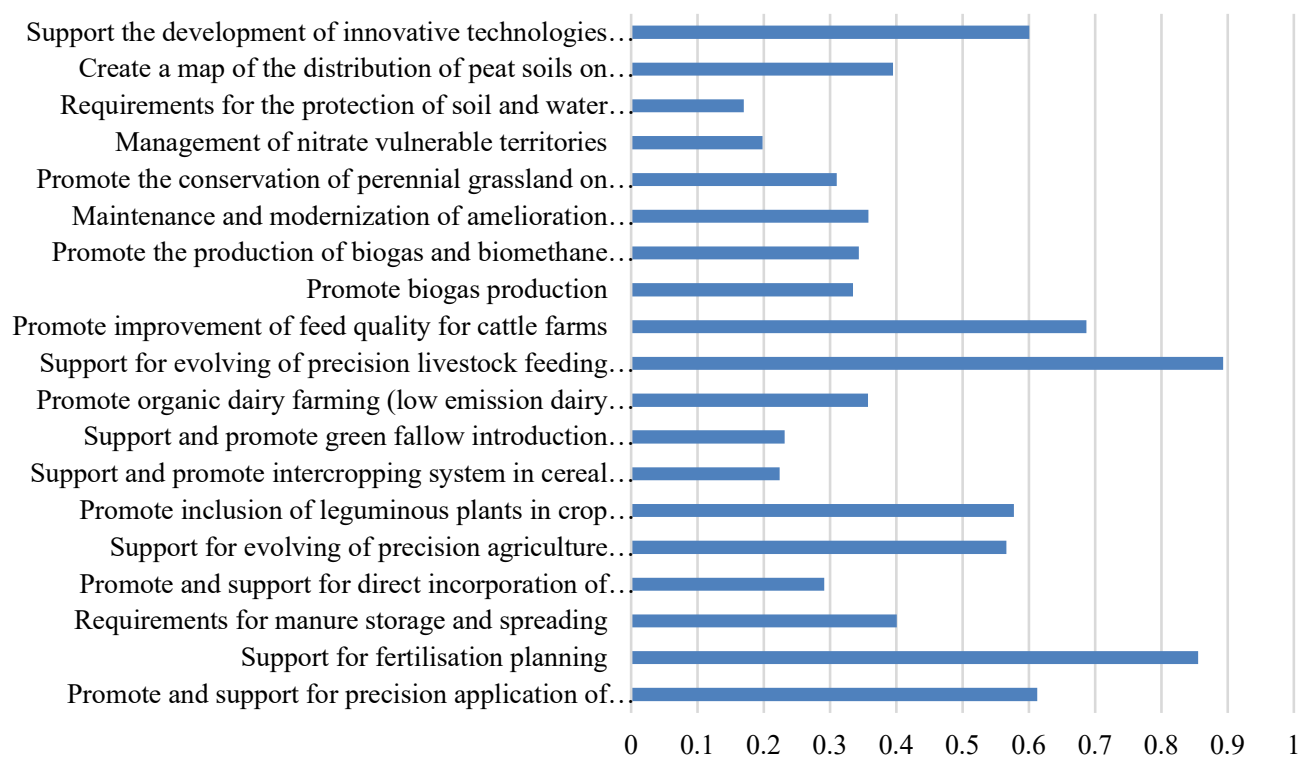

Fig. 3. Ranking of measures by TOPSIS.

The obtained results showed that, taking into account all criteria, the most effective measures are: promotion of precision cattle feeding approach, including the development of feeding plans and support good quality use of feed to increase digestibility; support the development of innovative technologies (e.g. the development of information and communication technologies [43]) and solutions to promote resource efficiency; GHG reduction $/ \mathrm{CO}_{2}$ sequestration in agriculture.

The first round of survey shows that, according to experts, there are farmers that do not trust new technologies and would like to work as usual. While mostly the young farmers are ready to change and move towards smart technologies thereby also on smart agriculture, support for fertilisation planning, promote improvement of feed quality for cattle farms.

Taking into account the results of the multi-criteria analysis, policies and measures were grouped in order of importance (see Table 2) and then asked for experts to forecast the leader of future measures for GHG emission reduction in the agricultural sector taking into account only the leading measures.

According to the second round of the survey, all involved experts forecasted that in the future the complex measure Support the development of innovative technologies and solutions to promote resource efficiency, $\mathrm{GHG}$ reduction $/ \mathrm{CO}_{2}$ sequestration will be at the top of all measures in the agricultural sector. This measure is forecasted to be one of the core measures to be developed within the implementation of sustainable and smart agriculture in the future. According to the view of experts in this survey, this measure could contribute to reduce GHG emissions considering sustainable agricultural management, animal rearing techniques, as well as nutrient management improvement, including precision farming. 
TABLE 2. GROUPED POLICIES AND MEASURES BY PRIORITY

\begin{tabular}{|c|c|c|c|c|c|}
\hline \multirow{2}{*}{$\begin{array}{c}\text { Priority } \\
\text { Leader } \\
(0.6-0.9)\end{array}$} & \multicolumn{5}{|c|}{ Policies and measures } \\
\hline & $\begin{array}{l}\text { Promote precision } \\
\text { cattle feeding } \\
\text { approach, including } \\
\text { feeding plans } \\
\text { development and } \\
\text { support good quality } \\
\text { use of feed to increase } \\
\text { digestibility }\end{array}$ & $\begin{array}{l}\text { Support for } \\
\text { fertilisation } \\
\text { planning }\end{array}$ & $\begin{array}{l}\text { Promote } \\
\text { improvement of } \\
\text { feed quality for } \\
\text { cattle farms }\end{array}$ & $\begin{array}{l}\text { Promote and } \\
\text { support for } \\
\text { precision } \\
\text { application of } \\
\text { inorganic } \\
\text { nitrogen } \\
\text { fertilisers }\end{array}$ & $\begin{array}{l}\text { Support the } \\
\text { development of } \\
\text { innovative } \\
\text { technologies and } \\
\text { solutions to } \\
\text { promote } \\
\text { resource } \\
\text { efficiency, GHG } \\
\text { reduction/CO } / \mathrm{O}_{2} \\
\text { sequestration }\end{array}$ \\
\hline $\begin{array}{c}\text { Strong } \\
(0.4-0.6)\end{array}$ & $\begin{array}{l}\text { Promote inclusion of } \\
\text { leguminous plants in } \\
\text { crop rotation for } \\
\text { nitrogen fixation }\end{array}$ & $\begin{array}{l}\text { Use of precision } \\
\text { agriculture } \\
\text { technologies in } \\
\text { farms for crop } \\
\text { growth to reduce } \\
\text { use of nitrogen }\end{array}$ & $\begin{array}{l}\text { Requirements } \\
\text { for manure } \\
\text { storage and } \\
\text { spreading }\end{array}$ & & \\
\hline \multirow[t]{2}{*}{$\begin{array}{l}\text { Moderate } \\
(0.2-0.4)\end{array}$} & $\begin{array}{l}\text { Create a map of the } \\
\text { distribution of peat } \\
\text { soils on agricultural } \\
\text { land }\end{array}$ & $\begin{array}{l}\text { Promote organic } \\
\text { dairy farming } \\
\text { (low emission } \\
\text { dairy farming) }\end{array}$ & $\begin{array}{l}\text { Promote biogas } \\
\text { and biomethane } \\
\text { production and } \\
\text { biomethane use }\end{array}$ & $\begin{array}{l}\text { Promote the } \\
\text { conservation } \\
\text { of perennial } \\
\text { grasslands on } \\
\text { livestock } \\
\text { farms }\end{array}$ & $\begin{array}{l}\text { Support and } \\
\text { promote } \\
\text { intercropping } \\
\text { system in cereal } \\
\text { growing }\end{array}$ \\
\hline & $\begin{array}{l}\text { Maintain and } \\
\text { modernise } \\
\text { amelioration systems } \\
\text { on agricultural land }\end{array}$ & $\begin{array}{l}\text { Promote organic } \\
\text { dairy farming } \\
\text { (low emission } \\
\text { dairy farming) }\end{array}$ & $\begin{array}{l}\text { Promote biogas } \\
\text { production }\end{array}$ & $\begin{array}{l}\text { Promote and } \\
\text { support for } \\
\text { direct } \\
\text { incorporation } \\
\text { of organic } \\
\text { fertilisers into } \\
\text { the soil }\end{array}$ & $\begin{array}{l}\text { Support and } \\
\text { promote green } \\
\text { fallow } \\
\text { introduction } \\
\text { before winter } \\
\text { crop sowing }\end{array}$ \\
\hline $\begin{array}{l}\text { Modest } \\
(0-0.2)\end{array}$ & $\begin{array}{l}\text { Management of nitrate } \\
\text { vulnerable territories }\end{array}$ & $\begin{array}{l}\text { Water and soil } \\
\text { protection } \\
\text { requirements } \\
\text { from pollution } \\
\text { related nitrates }\end{array}$ & & & \\
\hline
\end{tabular}

\section{CONCLUSION AND Discussions}

In this study key policies and measures within WEM and WAM scenarios for the agricultural sector were used in accordance with Latvia's BR4 and NECP to evaluate top GHG measures for emission reductions to mitigate climate change in the future. For this analysis, a combination of two approaches: Delphi method and MCA were used. The opinion of experts about the most appropriate measures for decreasing emissions was gathered in two rounds using the Delphi approach. A combination of the Delphi method and MCA allowed to range the measures in order of importance and then, in the second round, to ask experts to evaluate the most significant measure (from those analyzed) to combat climate change. The results show that, in the future, the measure Support the development of innovative technologies and solutions to promote resource efficiency, GHG reduction / $\mathrm{CO}_{2}$ sequestration in agriculture is essential to move on climate smart agriculture and net-zero emissions balance in 2050. At the same time, it should be noted that important environmental protection measures are management of nitrate vulnerable territories and water and soil protection requirements from pollution related nitrates which were grouped as modest 
priority. Making more intelligent/innovative farming will help to improve quality of products and agriculture sustainability as well as decrease costs. To implement this measure within the daily life of farmers, more training courses are necessary and support from the government is also needed. Therefore, to stimulate innovative technologies for decreasing GHG emissions and help farmers adapt to climate change a largescale transformative approach, including change in agriculture policy is needed. It is important that the creation and development of new technologies, higher value-added products and services requires the establishment of carbon farming practices, as well as investments in research as well. Furthermore, to achieve GHG emission reduction in agriculture sector without people changing behavior is not possible therefore activity in this field is very essential and policy makers should focus much more on it.

Usage of the combination of the above mentioned methods in policy planning could support policy makers with better results through already prescreened GHG mitigation measures for agriculture sector.

\section{ACKNOWLEDGEMENT}

This research is funded by the Ministry of Economics of the Republic of Latvia, project "Energy and climate modelling towards net zero emissions", project No. VPP-EM-2018/NEKP-0001.

\section{REFERENCES}

[1] Official statistics of Latvia. Official statistics portal. Population number, its changes and density. Population of rural and urban territories [Online]. [Accessed 03.01.2021]. Available: https://stat.gov.lv/en/statisticsthemes/population/population-number/247-population-number-its-changes-and-density

[2] Ministry of Economy. Latvijas ekonomikas attīstības pārskats (Latvian economic development report.). Rīga: MoE, 2019. (in Latvian)

[3] European Commission. Commission staff working document. Commission recommendations for Latvia's CAP strategic plan. SWD (2020) 386 final. Brussels: European Commission, 2020.

[4] Gancone A., et al. Latvia's National GHG Inventory report 1990 - 2018 to the UNFCCC. Riga: VARAM, 2020.

[5] Latvia's National Energy and Climate plan 2021. - 2030. Riga: Cabinet of Ministers, 2020.

[6] Gancone A., et al. Latvia's forth Biennial Report to the UNFCCC. Riga: VARAM, 2019.

[7] European Commission. Communication from the commission - The European Green Deal. COM/2019/640 final. Brussels: European Commission, 2019.

[8] Fusco G., et al. How to Improve the Diffusion of Climate-Smart Agriculture: What the Literature Tells us. Sustainability 2020:12(12):5168. https://doi.org/10.3390/su12125168

[9] Muizniece I., et al. Circular Economy and Bioeconomy Interaction Development as Future for Rural Regions. Case Study of Aizkraukle Region in Latvia. Environmental and Climate Technologies 2019:23(3):129-146. https://doi.org/10.2478/rtuect-2019-0084

[10] Pubule J., et al. Sectoral Greenhouse Gas Emission Mitigation Possibilities. Why Broad Spectrum of Indicators is Applied. Energy Procedia 2017:113:377-381. https://doi.org/10.1016/j.egypro.2017.04.015

[11] Brazdausks P., et al. Evaluation of cellulose content in hemp shives after salt catalyzed hydrolysis. Energy Procedia 2017:128:297-301. https://doi.org/10.1016/j.egypro.2017.08.316

[12] IPCC. Climate change 2014. Synthesis report. Geneva: IPCC, 2015.

[13] European Commission. A Farm to Fork Strategy for a fair, healthy and environmentally-friendly food system. COM/2020/381 final. Brussels: European Commission, 2020.

[14] Lipper L., Zilberman D. A Short History of the Evolution of the Climate Smart Agriculture Approach and Its Links to Climate Change and Sustainable Agriculture Debates. In Lipper L., McCarthy N., Zilberman D., Asfaw S., Branca G. (eds) Climate Smart Agriculture. Natural Resource Management and Policy 2018:52:13-30. https://doi.org/10.1007/978-3-319-61194-5 2

[15] Food and agriculture organization of the United Nations. CLIMATE-SMART AGRICULTURE Sourcebook. Rome: FAO, 2013.

[16] "Climate-Smart" Agriculture Policies, Practices and Financing for Food Security, Adaptation and Mitigation Food and Agriculture Organization of the United Nations. Rome: FAO, 2010.

[17] Lipper L., et al. Climate-smart agriculture for food security. Nature Climate Change 2014:4:1068-1072. https://doi.org/10.1038/nclimate2437 
[18] Amin A., et al. Climate Smart Agriculture: an approach for sustainable food security. Agricultural Research Communication 2015:2(3):13-21.

[19] Climate Smart Agriculture [Online]. [Accessed: 22.03.2021]. Available: https://www.iaea.org/topics/climate-smartagriculture

[20] Campbell B. M., et al. Sustainable intensification: What is its role in climate smart agriculture? Current Opinion in Environmental Sustainability 2014:8:39-43. https://doi.org/10.1016/j.cosust.2014.07.002.

[21] Pagliacci F., et al. Drivers of farmers' adoption and continuation of climate-smart agricultural practices. A study from northeastern Italy. Science of The Total Environment 2020:710:136345. https://doi.org/10.1016/j.scitotenv.2019.136345

[22] Climate-Smart Agriculture. World Bank [Online]. [Accessed: 22.03.2021]. Available: https://www.worldbank.org/en/topic/climate-smart-agriculture

[23] Long T. B., Blok V., Coninx I. The diffusion of climate-smart agricultural innovations: Systems level factors that inhibit sustainable entrepreneurial action. Journal of Cleaner Production 2019:232:993-1004. https://doi.org/10.1016/j.jclepro.2019.05.212

[24] Tesfai M., et al. Transition towards bio-based economy in small-scale agriculture in Sub-Saharan Africa through sustainable intensification. The Bioeconomy Approach. Constraints and Opportunities for Sustainable Development. London: Routledge, 2020.

[25] Senyolo M. P., et al. How the characteristics of innovations impact their adoption: an exploration of climate-smart agricultural innovations in South Africa. Journal of Cleaner Production 2018:172:3825-3840. https://doi.org/10.1016/j.jclepro.2017.06.019

[26] Khatri-Chhetri A., et al. Stakeholders prioritization of climate-smart agriculture interventions: Evaluation of a framework. Agricultural Systems 2019:174:23-31. https://doi.org/10.1016/j.agsy.2019.03.002

[27] Long T. B., Blok V., Coninx I. Barriers to the adoption and diffusion of technological innovations for climate-smart agriculture in Europe: evidence from the Netherlands, France, Switzerland and Italy. Journal of Cleaner Production 2016:112(1):9-21. https://doi.org/10.1016/j.jclepro.2015.06.044.

[28] Harold A. L., Turoff M., Helmer O. The Delphi Method Techniques and Applications. Boston: Addison-Wesley, 2002.

[29] Green R.A. The Delphi Technique in Educational Research. Education Theory and Practice, Educational Research, Research Methods 2014:4(2). https://doi.org/10.1177/2158244014529773

[30] Dick S., et al. The Delphi Method Research Strategy in Studies of Information Systems. Communications of the Association for Information Systems 2015:37:31-63. https://doi.org/10.17705/1CAIS.03702

[31] San-Jose L., Retolaza J. L. Is the Delphi method valid for business ethics? A survey analysis. European Journal for Futures Research 2016:4:19. https://doi.org/10.1007/s40309-016-0109-x

[32] Rowe G., Wright G., Expert Opinions in Forecasting. Role of the Delphi Technique. Principles of Forecasting: A Handbook of Researchers and Practitioners. In Armstrong J.S. (eds) Principles of Forecasting. International Series in Operations Research \& Management Science 2001:30:125-144. https://doi.org/10.1007/978-0-306-47630-3 7

[33] Pubule J., et al. Finding an optimal solution for biowaste management in the Baltic States. Journal of Cleaner Production 2015:88:214-223. https://doi.org/10.1016/j.jclepro.2014.04.053.

[34] Hwang C. L., Yoon K. Multiple Attribute Decision Making. Springer, 1981. https://doi.org/10.1007/978-3-642-48318-9

[35] Tzeng G. H., Huang J. J. Multiple Attribute Decision Making: Methods and Applications. Chapman and Hall/CRC, 2011. https://doi.org/10.1201/b11032

[36] UNFCCC. Report on the technical review of the fourth biennial report of Latvia. Bonn: UNFCCC, 2020.

[37] Bumbiere K., et al. Carbon balance of biogas production from maize in Latvian conditions. Agronomy Research 2021:19(1):687-697. https://doi.org/10.15159/AR.21.085

[38] Rivza P., et al. Greenhouse gas emission reduction opportunities with climate-friendly agriculture and forestry in Latvia. Jelgava: LLU, 2018. (in Latvian)

[39] Popluga D., Naglis-Liepa K. Evaluation of measures for mitigation of greenhouse gas emissions suitable for Latvian agriculture. Engineering for Rural Development 2015:584-589.

[40] Bumbiere K., et al. Ranking of Bioresources for Biogas Production. Environmental and Climate Technologies 2020:24(1):368-377. https://doi.org/10.2478/rtuect-2020-0021.

[41] Bumbiere K., Pubule J., Blumberga D. What Will Be the Future of Biogas Sector? Environmental and Climate Technologies 2021:25(1):295-305. https://doi.org/10.2478/rtuect-2021-0021.

[42] Naglis-Liepa K., Popluga D. Integrated impact assessment of agricultural GHG abatement measures.2018. Proceedings of the 2018 International Conference "Economic science for rural development" 2018:49:77-83. https://doi.org/10.22616/ESRD.2018.121

[43] Oliveira M. F., et al. Innovations in Sustainable Agriculture: Case Study of Lis Valley Irrigation District, Portugal. Sustainability 2019:11(2):331. https://doi.org/10.3390/su11020331. 